\title{
SUSTAINABLE MANAGEMENT OF LAND RESOURCES AND ORGANIC FARMING
}

\author{
N. Petrova* \\ Department of Management, Faculty of Economics, Trakia University, Stara Zagora, Bulgaria
}

\begin{abstract}
Soil, as a component of the environment, is an indispensable, limited and unrecoverable natural resource. This requires its protection from harmful effects and its sustainable use. The aim of the study is to analyze the status of land resources and reveal the possibilities of organic farming for sustainable use. The methods used are systematic and comparative analysis; Method of statistical groupings, expert assessments, inductive and deductive methods for generalizing summaries. Expectations from the study are that opportunities for increasing sustainability in land resource management will be revealed through increased organic farming.
\end{abstract}

Key words: Soil, sustainable use, natural resource

\section{INTRODUCTION}

Sustainable management of land resources (soils, water, plants and animals) is a process in which their use in the production of raw materials, products and services preserves the long-term productive potential of these resources. In this sense, the sustainable management of land resources has the main purpose of preserving the soil's multifunctional capacities - productive, buffer, carrier, filtering as well as a source of raw materials, habitat for biological species, environment for storing genetic resources, carrier and guardian of the genetic and cultural heritage of mankind, ensuring ecological balance in ecosystems.

The need for sustainable use and management of land-based resources originates also from their limitations on our planet. They are twice as low as the water surface.

\section{MATERIAL AND METHODS}

The methods used are systematic and comparative analysis; Method of statistical groupings, expert assessments, inductive and deductive methods for generalizing summaries.

\section{RESULTS AND DISCUSSION}

Land resources are a factor of particular importance for the development of each country. They are a territorial basis for each human activity and play a different role in the

*Correspondence to: Nadejda Petrova, Department of Management, Faculty of Economics, Trakia University, Stara Zagora, Bulgaria, Email: nfp@abv.bg, Tel: +359-42-699-411 different branches of material production. These differences are most clearly demonstrated by comparing land use in agriculture and industry. In the processing industry, construction and transport, the land serves as a foundation, a spatial area on which housing, cities, large technical facilities, water reservoirs, communication facilities and the like are located. In agriculture, the land has a different purpose. It is an essential tool for production, it is of great economic importance and an indispensable natural resource. This requires that land resources be used economically, primarily to meet the population's food needs by limiting the use of arable land for non-agricultural purposes. Depending on its suitability for agriculture, this land fund is divided into three categories of land:

-Unproductive lands - glaciers, deserts, rocks, sandy stripes; lakes, rivers, reservoirs; city roads, industrial sites; anthropogenic bedland; agricultural non-productive territories / villages, etc. /

-Productive lands not suitable for processing tundras, marshes, dry steppes and savannas, salted soils, forests and marshy soils;

-Arable lands - modern arable land and plantations, meadows and pastures;

Very often the two concepts of "land" and "soil" are used as equivalents, but this is not correct. Earth is a part of the land, of the Earth surface. 
It includes biosphere elements that are below and above it: soil, soil-forming rock, laying base, groundwaters, plant and animal species, microorganisms, human activity results, atmosphere. Soil is the surface layer of the earth's crust that has fertility, and the fertility of the soil is its ability to simultaneously provide plants with water, the necessary nutrients and air, as well as to create favorable conditions for growth and development. Soil is a major natural resource that people use to their advantage. Without it their existence is impossible. Human activity has given and gives deep impacts on the soil. The solution to the problem about providing the Earth population with food depends to a large extent from the proper and careful use of the soil, the maintenance and increase of its fertility.

The food problem is one of the most important for man's existence. It is expressed by the possibilities for meeting the non-stop growing needs of mankind for food in different parts of the world. The so-called "traditional" or "conventional" farming system is applied to solve the food problem of mankind. It uses all the achievements of scientific and technical progress and is characterized as intensive, with high inputs of production factors. It includes intensive mechanical cultivation of the soil such as deep plowing, harrowing, and the like. Plant protection is based on both intensive mechanical treatments and extensive use of herbicides, pesticides, and others, chemical agents for control of diseases and pests of crop plants. The main feature that distinguishes the traditional farming system from other agricultural systems is the mechanical way of soil treatment and maintenance of soil fertility. This leads to increased productivity and lower harvest losses, but in the long run there are also significant shortcomings:

- Accelerating the mineralization of organic matter and loss of humus;

-Breach of nutritional balance in soil and plant nutrition;

- Digging into of the fertile surface layer;

- Digging into plant residues and deprivation of the soil surface against erosion protection, etc.

-Reduction of the soil biodiversity and the amount of biomass (rain worms, insects, fungi, and the like) that are important for soil formation;

- Compaction of the soil due to the large number of working operations and increase in the weight of the working machines and their power.

These deficiencies lead to degradation of resources, which is a sure sign of instability.
The farmer is faced with the whole system of negative climatic changes - prolonged droughts, rising temperatures, devastating floods, plant and animal diseases and pests (much of them unfamiliar), biodiversity loss, etc. At the present stage in solving the food problems, mankind is faced not only by the impossibility of eliminating hunger, but also by coping with the problems of environmental pollution, caused by the development of food industries. This requires the use of environmentally sustainable farming practices. An example of such practice is the organic farming. It not only keeps the soil healthy, fertile and natural, but also improves its condition by providing the right nutrients, structural improvements and effective irrigation.

"Organic farming includes all farming systems producing food and fiber that are environmentally, socially and economically consistent. These systems use the natural fertility on the land as a key factor in production. Considering the natural productivity of plants, animals and land, they aim to optimize all aspects of agriculture and the environment. Organic farming drastically reduces external inputs to the agro-ecosystem, refraining from the use of synthetic fertilizers, pesticides and medicaments. Instead, it leaves natural laws to act with full force to increase agricultural crops and increase disease resistance "(IFOAM).

The purpose of the organic production system is to:

Enhance biodiversity across the system;

Increase biological activity in the soil;

Maintain long-term soil fertility;

Recycle waste of plant and animal origin to restore nutrients to the soil, minimizing the use of non-renewable resources;

Rely on renewable resources from local agroecosystems;

Promote a sparing use of soil, water and air, minimizing all forms of pollution that may have an effect on agricultural production;

Process agro products with emphasis on methods that preserve the valuable taste and nutritional qualities of the product at all stages of processing.

Organic farms do not use chemically and artificially created pesticides, herbicides, synthetic fertilizers, sewage, genetically modified organisms (GMOs), antibiotics or artificial radiation in the production of plants and animal breeding.

In the last years organic farming in Bulgaria 
has been one of the sectors that, in times of crisis, is developing at a rapid pace, with constantly increasing areas and number of operators, involved in a control system.

The reasons are related to the very good prerequisites for the development of organic farming in our country - ecologically preserved areas; awareness and willingness of consumers to eat healthily; The perceived environmental and rural benefits; support for organic farmers under the Rural Development Program, with the efforts of the MAF in partnership with business and non-governmental organizations in the sector to promote the benefits to producers and consumers of this type of products and food.

Organic farming areas are increasing in the EU and in Bulgaria, thanks in particular to payments from the EU.

By the end of 2015 the total number of biological operators registered in MAFs was 6 173 - by 2,081 more compared to the previous year (Table 1).

Table 1. Number of operators (producers, operators, traders) and areas in organic production in Bulgaria

\begin{tabular}{|l|l|l|l|l|l|l|l|l|l|l|}
\hline Indices & 2006 & 2007 & 2008 & 2009 & 2010 & 2011 & 2012 & 2013 & 2014 & 2015 \\
\hline $\begin{array}{l}\text { 1.Number of } \\
\text { operators in } \\
\text { organic } \\
\text { farming }\end{array}$ & 214 & 339 & 311 & 476 & 820 & 1054 & 2016 & 3123 & 4092 & 6173 \\
\hline $\begin{array}{l}\text { 2.Total areas in } \\
\text { the control } \\
\text { system (in and } \\
\text { after } \\
\text { transition)hecta } \\
\text { res }\end{array}$ & 5952 & 15224 & 16662 & 11789 & 25647 & 26662 & 40378 & 58107 & 7435 & 11857 \\
\hline
\end{tabular}

Source: MAF, based on data from the annual reports of the control bodies of organic production

Compared to 2006, the year before Bulgaria's membership in the EU, the increase in operators in the control system is about 30 times. Compared to 2009, the year since new European legislation on organic farming has been applied, in 2015 the number of operators in the control system has grown 13 times. Unlike other agricultural sectors, organic production grows not in percent, but in times. There is also a significant increase in the areas covered by the organic production control system - they reached 118571 ha. Certified ecologically clean areas from which wild crops are harvested - mushrooms, herbs and berries are not included in this figure. Compared to 2006, the area increase is almost 20 times. The share of the biologically cultivated land for 2015 is $2.4 \%$ of the utilized agricultural area in the country, while in 2006 it was only $0.1 \%$.

\section{CONCLUSION}

The steady increase in the number of certified organic producers and certified organic farming areas shows that organic farming has a prospect. It directly contributes to preserving the environment and ecosystems, restoring natural resources, developing rural areas. It can stabilize the incomes of Bulgarian farmers through the opportunity to provide healthy food products in new markets. Thus the competitive advantage of the natural and climatic conditions in our country and the support of the European funds will be reimbursed in economic benefits by the farmers.

\section{REFERENCES}

1. Agricultural Report of MAF, 2016.

2. Aleksiev G., R. Otuzbirov, Biological Beekeeping in Bulgaria - Problems and Perspectives, Reports "Agribusiness and Rural Areas - Present and Future Development", Varna, pp. 355-360, 2015.

3. COUNCIHL REGULATION (EC) N: 2092/91 on organic production of africultural and indication referring thereto on agricultural products and foodstuffs. Official Jurnal of the Europian Communities No L 189/1, 20. 7. 2007. http://europa.eu/scadplus/leg/en/lvb/

4. Eurostat: Farm Structure Survey data (holdings, labour use, age and sex of farm managers, education and vocational training):

http://ec.europa.eu/eurostat/data/database

5. Gonzalvez,V.,0. Schmid, H.WiIIer. Organic Action Plans in Europe in 2011. In: Wilier, H. and Kilcher, L. eds., 2011.

6. IFOAM (International Federation of Organic Agriculture Movements): webpage at: www.ifoam.org. 
7. Kostadinova, N., Organic Agriculture in Bulgaria - Perspectives and Opportunities, Reports "Agribusiness and Rural Areas Present and Future Development", Varna, pp. 325-331, 2015.

8. Lampkin N. Organic Farming, Old Pond Publishing Ltd. ISBN: 9781903366295; ISBN (Ten digit): 1903366291,2002. http://www.booksunlimited.ie/Books/Lamp kinN./OrganicFarming/9781903366295.htm

9. Mikova, D., Biological Production priority of Bulgarian Agriculture in the
New Programming Period 2014-2020, revue., Economy and Agriculture Management, issue 3, EIA, Sofia, p.4-7, 2014.

10.National Strategy for Sustainable Development of Agriculture in Bulgaria, 2015.

11.Nikolov R., Organizational and Economic Aspects of Conservation Agriculture in Bulgaria, Dissertation, University of Varna, 2016. 